\title{
Habitat Preference of the Greater One-Horned Rhinoceros (Rhinoceros unicornis Linn.) in the Baghmara Buffer Zone Community Forest, Chitwan National Park, Nepal
}

\author{
Anupa Gurung and Mukesh Kumar Chalise \\ Central Department of Zoology, Tribhuvan University, Kirtipur, Kathmandu, Nepal
}

For correspondence: mukesh57@hotmail.com

\begin{abstract}
The Greater One-Horned Rhinoceros (Rhinoceros unicornis Linn.) is listed in Appendix I of the Convention on International Trade in Endangered Species of wild fauna and flora (CITES). A year round (October 2010 to September 2011) research was conducted in the Baghmara Buffer Zone Community Forest (BBZCF), located in the central lowland of Nepal, covering an area of 215 hectares, to collect information on the habitat types of the study area and the habitat preference of the Greater One-Horned Rhinoceros in that area. A total of four nested quadrates $(n=4)$ that were already laid on transects traversing east to west were randomly selected to collect information about the habitat types and the habitat preference of the Greater One-Horned Rhinoceros in the study area. The four nested quadrates, representing the major habitat types of the study area, were laid in four different sites of the Community Forest, Bandevi area (Forest habitat type), Kholsa forest area (Riverbed Forest habitat type), Macchan area (Grassland habitat type) and Riverside forest area near the Budi Rapti River (Riverside Forest habitat type). On the basis of the observed frequency of the animal locations and the availability of their indirect signs studied in the four habitat types of the study area, it was found that the Greater One-Horned Rhinoceros preferred the Grassland habitat type the most in the winter and the monsoon seasons; and likewise the Forest habitat type in the summer season as their habitats.
\end{abstract}

Key words: Bandevi, BBZCF, Grassland, Kholsa, Machan

\section{Introduction}

Habitat is a complex mixture of plant communities, water, weather, animals and other environmental features that provide food and cover that an organism needs. Habitat is the home of the wildlife. When the habitat factors are in a good supply, they contribute to the well being of the wildlife and if any one of these factors is in a short supply, the wildlife number and location in that habitat are limited. Habitat may be selected for cover availability, forage quality and quantity and resting or den sites, each of which may vary seasonally. The preference of habitat by an organism is the consequence of habitat selection and this result in the disproportional use of some resources over the others.

This research work was conducted in the Baghmara Buffer Zone Community Forest, which has an advantage of having direct land-linkage with Chitwan National Park, the original habitat of the Greater One-Horned Rhinoceros. The Greater One-Horned Rhinoceros is listed in Appendix I of the Convention on International Trade in Endangered Species of wild fauna and flora (CITES). The species was

Nepalese Journal of Zoology | Online Volume 3 Issue 1 | November 2015 | Page 28 
categorized under IUCN criteria as Endangered for a long period until the relative recovery of a single population in India (Kaziranga National Park) resulted in down-listing to vulnerable category on the IUCN Red List of Threatened species (IUCN 2008). The Government of Nepal has regarded the Greater One-Horned Rhinoceros in the list of protected animals and has been conducting various conservation programs in collaborations with different conservation partners (Chalise 2008).

The Greater One-Horned Rhinoceros (Rhinoceros unicornis Linn.), belonging to the family Rhinocerotidae, is a large mammal primarily found in the parts of north-eastern India and in protected areas in the Tarai of Nepal. This heavily built species is the second largest living rhino next to the White Rhino. The adult male rhinos weigh up to 2100 kilogram and stand up to 186 centimeter at the shoulder. While the adult female rhinos reach weights of about 1600 kilogram and heights of 160 centimeter. The rhino skin, which is thick and silver-brown in colour, becomes pinkish near the large skin folds that cover its body. The upper legs and shoulders are covered in wart-like bumps. The rhino's single horn, present in both males and females (but not on newborn young), is pure keratin and starts to show about six years and is normally between 15 and 45 centimeter long (Chalise 2008).

The rhinos are mostly solitary creatures, with the exception of mothers and calves and breeding pairs, although they sometimes congregate at bathing areas. Mothers will stay close to their calves for up to four years after their birth; sometimes allowing an older calf to continue to accompany her once a newborn calf arrives. Being a solitary and primitive herbivorous mammal, the rhino shows distinct behavioral characteristics. Laurie $(1978,1982)$ has done remarkable studies on the behavioral activities (both diurnal and nocturnal), which covered feeding behavior, drinking behavior, aggressive behavior, non-breeding play behavior and reproductive behavior, etc. Activity takes place mostly at night, early in the morning and in the late afternoon (Laurie 1978), but in the middle of the day, the rhinos are commonly seen resting in the shade or mud; and wallowing and bathing in the lakes, rivers and pools. The rhinos are excellent swimmers and they can run at speeds up to 55 kilometer/hour for short periods of time. They also have excellent senses of hearing and smell, but relatively poor eyesight.

The rhino is a grazer. The rhino feeds mainly on grasses; and also fruits, leaves, branches of trees and shrubs; and cultivated crops (Jnawali 1989). Feeding occurs during the morning and evening. When feeding on tall grasses, the rhino curls its prehensile upper lip around the grass stems, bends the stems over and bites off, and chews the top (Laurie 1978). Drinking takes place on a daily basis. Drinking normally lasts only a minute or two and mineral licks are visited regularly (Laurie 1978). The rhino requires special habitat conditions including wallows, grasslands, woodlands and forest cover. The rhino spends about 8 hours/day in wallows or streams during the period of high humidity (August-September) but they spend at least an hour/day wallowing in December and January (Laurie 1978). The Asiatic rhino species prefer to reside in alluvial flood-plain vegetation of sub-tropical climate where water and green grasses are available all year round. Their phylogeny, ecology and nutritional energetic have evolved around these grassland ecosystems. The other preferred habitat includes marshy lowland Sal forest, wooded grassland and riverbeds. In Nepal, many rhinos now live within blocks of the suitable rhino habitat in Chitwan National Park. The rhinos occurred in highest densities along the flood-plain grasslands and riverine forests bordering the Rapti, Narayani, Reu and Dhungre rivers, suggesting that the flood-plain grasslands dominated by 4-6 meter tall Saccharum spontaneum are the single critical habitat (Dinerstein and Price 1991).

Nepalese Journal of Zoology | Online Volume 3 Issue 1 | November 2015 | Page 29 


\section{Materials and Methods}

\section{Study area}

The Baghmara Buffer Zone Community Forest is situated on the North-East boundary of Chitwan National Park in Bachhauli Village Development Committee of Chitwan district, covering an area of 215 hectares. It lies between $27^{\circ} 34^{\prime} 78^{\prime \prime}$ to $27^{\circ} 35^{\prime} 53^{\prime \prime}$ northern latitude and $84^{\circ} 28^{\prime} 43^{\prime \prime}$ to $84^{\circ} 29^{\prime} 40^{\prime \prime}$ eastern longitude, in the sub-tropical region of lowland Nepal. The Baghmara Buffer Zone Community Forest borders the cultivated land to the east, Budhi Rapti to the west and the north, and Badreni village and Rapti River to the south.

The climate of the study area is sub-tropical with a summer monsoon from mid June to late September and a relatively dry winter. Humidity is high all-year round. Winter lasts from October to the end of February. January is the coldest month, with temperatures falling almost to freezing-point, especially when it rains. March to early June is the traditional hot months, with temperatures rising progressively to a peak in May. During April, despite the heat of the day, the nights can be quite cold. Heavy flooding occurs during the monsoon.

The dominant species of the Community Forest are Simal (Bombax ceiba), Bhellar (Trewia nudiflora) and Padke (Albizia julibrissin). The Community Forest that was once degraded and deprived of wildlife has now become a vibrant habitat for over 20 species of mammals and 162 species of birds. This Community Forest has harbored the Rhino (Rhinoceros unicornis), Spotted Deer (Axis axis), Sambhar Deer (Cervus unicolor), Barking Deer (Muntiacus muntjack), Hog Deer (Axis porcinus), Wild Boar (Sus scrofa), Rhesus Monkey (Macaca mulatta) and the Royal Bengal Tiger (Panthera tigris) (Pant 2003, Sharma et al 2013).

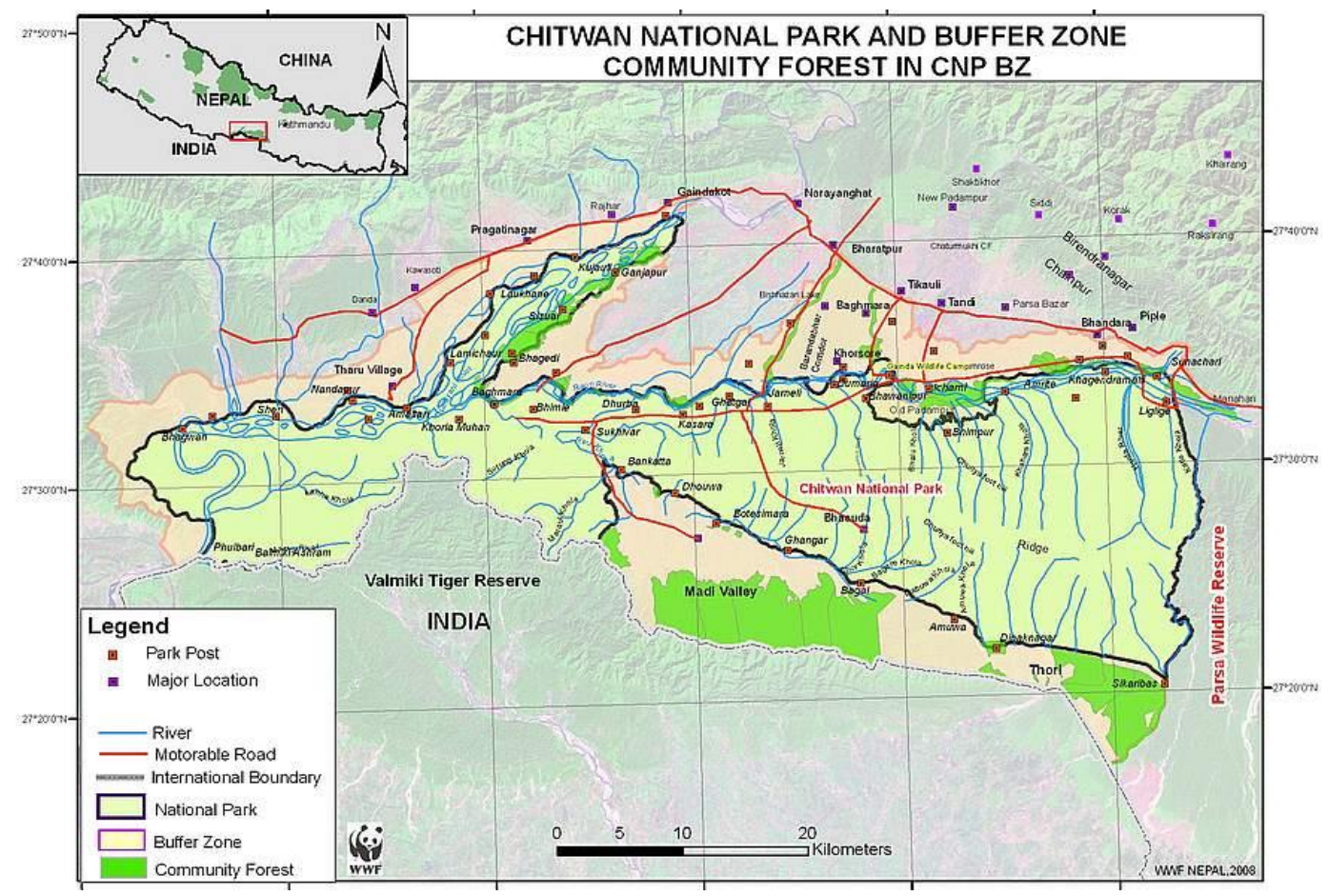

Figure 1. Location and Physical Parts of Chitwan National Park in Nepal.

Nepalese Journal of Zoology | Online Volume 3 Issue 1 | November 2015 | Page 30 


\section{Method}

A year round (October 2010 to September 2011) research was conducted in the Baghmara Buffer Zone Community Forest to collect information on the habitat types and the habitat preference of the Greater One-Horned Rhinoceros in the study area. A total of four nested quadrates $(n=4)$ that were already laid on transects traversing east to west were randomly selected to collect information about the habitat types and indirect signs of the Greater One-Horned Rhinoceros in the study area. Nested quadrates of 400 square meters ( 20 meter x 20 meter), 25 square meter ( 5 meter x 5 meter) and 1 square meter ( 1 meter x 1 meter) were used to collect data on tree, under-story and ground vegetation respectively.

\section{Habitat Utilization Pattern}

All the sightings of the rhinos and their every indirect signs in the different habitat types of the study area, with respect to the age-sex composition and the habitat types were recorded to study the habitat utilization pattern. During the investigation, the vegetation types of the areas wherever the animals were observed and their every activity were recorded, as well as, any indirect signs, such as, fresh wallow uses, footprints, dung heaps and feeding signs, if observed were also noted down as indirect evidences of the rhino visit in the habitat. The indirect signs of the animal were also collected from 400 square meter, 25 square meter and 1 square meter quadrates of the four study sites of the Community Forest. A total of 25 quadrates were surveyed in the Baghmara Buffer Zone Community Forest (Table 1).

Table 1. Total Number of Quadrates Surveyed in Different Habitat Types of the Baghmara Buffer Zone Community Forest in 2011.

\begin{tabular}{|l|c|c|c|c|}
\hline \multirow{2}{*}{ Habitat Types } & \multicolumn{2}{|c|}{ Number Of Quadrates Surveyed } & \multirow{2}{*}{ Total } \\
\cline { 2 - 4 } & Tree & Under-story & $\begin{array}{c}\text { Ground } \\
\text { Vegetation }\end{array}$ & \\
\hline Forest & 1 & 2 & 4 & 7 \\
\hline Riverbed Forest & 1 & 2 & 4 & 7 \\
\hline Grassland & - & - & 4 & 4 \\
\hline Riverside Forest & 1 & 2 & 4 & 7 \\
\hline Total & $\mathbf{3}$ & $\mathbf{6}$ & $\mathbf{1 6}$ & $\mathbf{2 5}$ \\
\hline
\end{tabular}

\section{Habitat Preference}

Habitat preference was evaluated by comparing the frequency distribution of the animal locations on the different habitat types within the study area. Here, the observed frequency of the animal locations included not only the different habitat types which the rhinos were noticed using in each season; but also all those habitat types in which the animal signs were also found. Those signs were the indirect evidences which showed the physical presence of the animals and the habitats were used by the animals. So, all the habitat types which the rhinos were observed using and where the rhino signs were found were considered as the preferred habitat types by the animal.

In calculating the Important Value Index (IVI), the percentage values of the relative density, relative frequency and relative dominance were summed up together and the value was designated as the Importance Value Index (IVI) of the species (Krebs 1989). Relative Density was the study of numerical strength of a species in relation to the total number of individuals of all the species. Relative Frequency

Nepalese Journal of Zoology | Online Volume 3 Issue 1 | November 2015 | Page 31 
was the degree of dispersion of individual species in an area in relation to the number of all the species occurred. Relative Dominance of trees was determined by calculating the basal area. Tree basal area was the cross-sectional area of a tree's trunk at 1.3 meter off the ground, which was approximately chestheight.

Prominence Values (PV) of individual species in under-story or ground layers was calculated by multiplying the percent cover of individual species and square root of its frequency (Dinerstein 1979).

\section{Results}

The study revealed that the rhinos utilized four major habitat types in the study area, Forest habitat type, Riverbed Forest habitat type, Grassland habitat type and Riverside Forest habitat type.

Among the four nested quadrates studied, three contained 105 individuals of trees of six species. The Important Value Index (IVI) of Bhellar (Trewia nudiflora) (110.534 percentage) was found to be the maximum, followed by that of Padke (Albizia julibrissin) (103.059 percentage) and then that of Dhamin (Dysoxylum binectariferum) (33.853 percentage) and Aureli Kanda (Caesalpinia decapetala) (19.538 percentage) and Kalo Bilaune (Antidesma acuminatum) (16.508 percentage) and Ban Belauti (Psidium guajava) (16.508 percentage) respectively. In the under-story layer of the forest habitat type, Bhati (Clerodendrum viscosum) was found to be the most prominent species ( $\mathrm{PV}=582.521$ percentage). In the ground vegetation of the forest habitat type, Pipla species was found to be the most prominent species $(\mathrm{PV}=244.524$ percentage). Similarly, in the under-story layer of the riverbed forest habitat type, Bilaune (Maesa species) was found to be the most prominent species ( $\mathrm{PV}=265.149$ percentage) and Himalayan Maiden Hair Fern (Adiantum venustum) was found to be the most prominent species ( $\mathrm{PV}=183.712$ percentage) in the ground vegetation of the riverbed forest habitat type. Likewise, in the grassland habitat type, Chepte Jhar species was found to be the most prominent species ( $\mathrm{PV}=105.399$ percentage).

\section{Habitat Use by the Rhino in the Baghmara Buffer Zone Community Forest in Different Season of the Year}

The study showed that the observed rhinos used different habitat types in different seasons in the Baghmara Buffer Zone Community Forest. In general, all the individual rhinos intensively used the forest habitat type and the grassland habitat type, which was then followed by the riverbed forest habitat type. The riverside forest habitat type was used in low frequency. Similarly, the individual rhinos used the grassland habitat type the most, followed by the riverbed forest habitat type and then the forest habitat type in the winter season. The forest habitat type was extremely used by the individual rhinos in the summer season. Likewise, the individual rhinos used the grassland habitat type frequently followed by the forest habitat type in the monsoon season.

Nepalese Journal of Zoology | Online Volume 3 Issue 1 | November 2015 | Page 32 
Table 2. The Observed Frequency of Habitat Use by the Observed Rhinos in the Different Seasons in the Baghmara Buffer Zone Community Forest (October 2010 to September 2011).

\begin{tabular}{|c|c|c|c|c|c|}
\hline \multirow[t]{2}{*}{ Name Of Animal } & \multicolumn{4}{|c|}{ Habitat Types } & \multirow[t]{2}{*}{ Total } \\
\hline & Forest & $\begin{array}{c}\text { Riverbed } \\
\text { Forest }\end{array}$ & Grassland & $\begin{array}{c}\text { Riverside } \\
\text { Forest }\end{array}$ & \\
\hline Adult Female (Winter) & 2 & 4 & 6 & - & 12 \\
\hline Adult Female (Summer) & 5 & - & & - & 5 \\
\hline Adult Female (Monsoon) & 4 & - & 5 & - & 9 \\
\hline Adult Male (Monsoon) & - & - & - & 1 & 1 \\
\hline Calf Male (Winter) & 2 & 4 & 6 & - & 12 \\
\hline Calf Male (Summer) & 5 & - & - & - & 5 \\
\hline Calf Female (Monsoon) & 4 & - & 5 & - & 9 \\
\hline Unidentified $*$ & 2 & 1 & 1 & - & 3 \\
\hline Total & 24 & 9 & 23 & $\mathbf{1}$ & 57 \\
\hline Percentage $(\%)$ & $42.11 \%$ & $15.79 \%$ & $40.35 \%$ & $1.75 \%$ & $100 \%$ \\
\hline
\end{tabular}

(* Indirect signs, such as, dung heaps, fresh wallow uses and footprints of the observed rhinos recorded.)

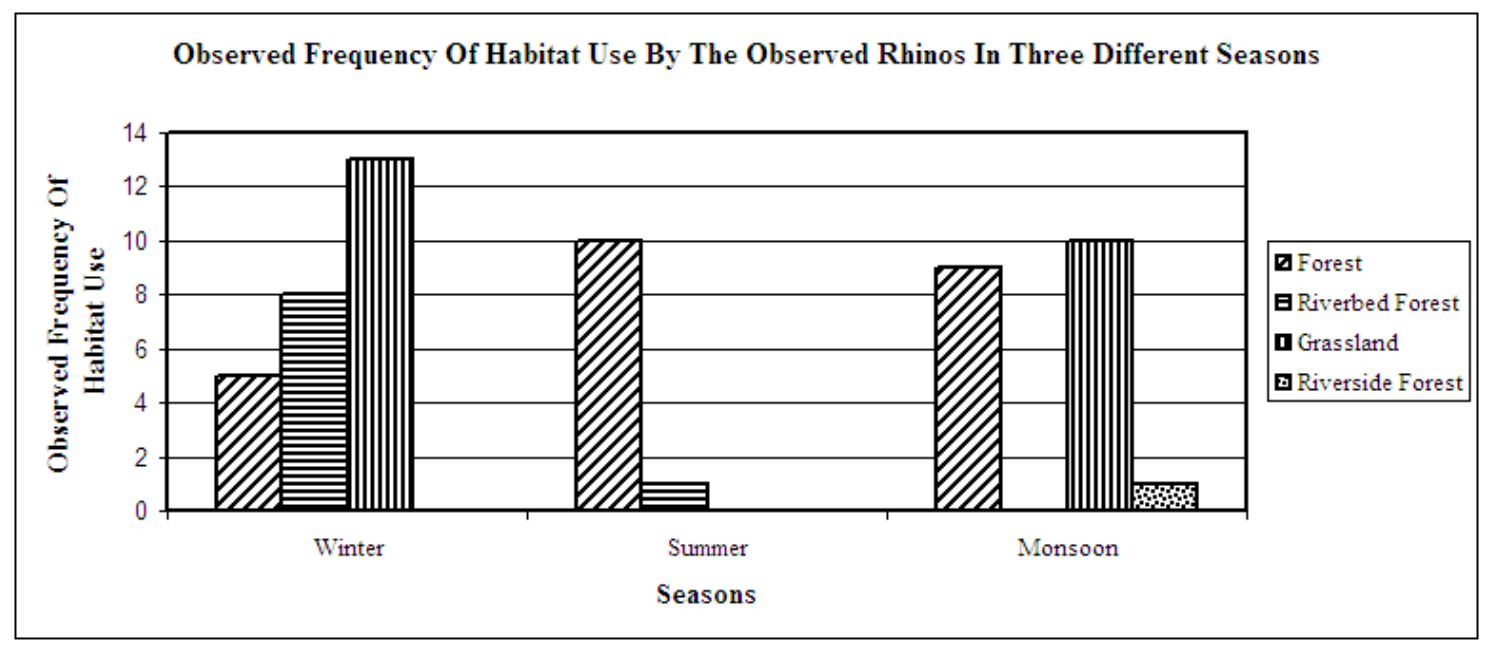

Figure 2. The Observed Frequency of Habitat Use by the Observed Rhinos in Three Different Seasons in 2011.

\section{Habitat Preference}

In the Baghmara Buffer Zone Community Forest, the observed rhinos showed a marked preference towards the forest habitat type, the grassland habitat type and the riverbed forest habitat type, whereas, the riverside forest habitat type was significantly avoided (Table-2). More precisely, in the winter season, the observed rhinos preferred the grassland habitat type the most, which was then followed by the riverbed forest habitat type and then the forest habitat type. There was no sign of utilization of the riverside forest habitat type in the winter season. While in the summer season, the forest habitat type was extensively preferred by the observed rhinos. Also, an indirect sign of fresh wallow use in the riverbed forest habitat type too indicated the preference of that habitat type by the rhinos in the summer season. Similarly, the Nepalese Journal of Zoology | Online Volume 3 Issue 1 | November 2015 | Page 33 
grassland habitat type and then the forest habitat type were much preferred by the observed rhinos in the monsoon season. The riverside forest habitat type was preferred in low frequency by the observed rhinos in the monsoon season, whereas, the riverbed forest habitat type was completely avoided.

\section{Discussion}

The present study showed that in the three out of the four nested quadrates studied, Bhellar (Trewia nudiflora) (IVI=110.534 percentage) had a higher or major controlling influence by its number and its size in the tree canopy layer, followed by Padke (Albizia julibrissin) (IVI= 103.059 percentage) then by Dhamin (Dysoxylum binectariferum) (IVI= 33.853 percentage) then by Aureli Kanda (Caesalpinia decapetala) (IVI= 19.538 percentage) then by Kalo Bilaune (Antidesma acuminatum) (IVI= 16.508 percentage) and by Ban Belauti (Psidium guajava) (IVI=16.508 percentage) respectively. The study showed that Bhellar (Trewia nudiflora) which was one of the main planted species in the study area happened to be an important tree species in the three nested quadrates and Padke (Albizia julibrissin) which was not the planted species in the study area appeared to be the second most important tree species in the tree canopy layer. It shows that the soil of the study area is suitable for the succession of the tree species. The number of the tree species in the tree canopy layer in the forest, the riverbed forest and the riverside forest habitat types was six and Bhellar (Trewia nudiflora), the most important tree species in the canopy layer, offers the favourite fruits for the rhinos, and hence, offers a good habitat for the rhinos. In the grassland habitat type, Chepte Jhar species ( $\mathrm{PV}=105.399$ percentage) was found to be the most prominent species, followed by Dubo (Cynodon dactylon) ( $\mathrm{PV}=75.434$ percentage). The species diversity in the grassland habitat type appeared to be rich in all the seasons and hence, provided a suitable habitat for the rhinos throughout the year.

The present study revealed that the rhinos exhibited seasonal differences in the habitat use and preference and intensively used and preferred the forest habitat type and the grassland habitat type, followed by the riverbed forest habitat type, in general. Whereas, the riverside forest habitat type was used and preferred in low frequency throughout. Furthermore, in detail, in the winter season, the grassland habitat type was preferred the most by the rhinos, followed by the riverbed forest habitat type and then the forest habitat type. Moreover, the present study also revealed that the forest habitat type was extremely preferred by the rhinos in the summer season and the grassland habitat type was preferred more followed by the forest habitat type in the monsoon season. The difference observed in the frequency distribution of the rhino locations in the different habitat types of the study area can be presumably explained by the fact that in the natural habitats the resources, such as, food, water and cover are not distributed uniformly. Also, the considerable seasonal variations in the availability of the food in the study area may have resulted in the movements of the rhinos between the different habitat types.

The major preference for the grassland habitat type in the winter season may have been due to the occurrence of the preferred food species of the rhinos, such as, the new flush of Tinpate Jhar (Trifolium repens), Dubo (Cynodon dactylon) after the periodic burning in the habitat type, the easy access to the sun basking in the chilly winter days and the availability of the open land for different activities like running, playing. Likewise, the extreme preference of the forest habitat type by the rhinos during the summer season may be explained by the fact that the forest provided the rhinos with their preferred fodder plant species, such as, young leaves of Bilaune (Maesa species), Bhati (Clerodendrum viscosum); cover from the intense summer heat and most importantly, the several, small water holes formed at places due to the summer rain in the forest allowed the animals for wallowing during the daytime. Majority of the summer time was spent in wallowing in different wallow sites in the different forest habitat types by the rhinos. The abundant presence of the preferred food species of the rhinos in the grassland habitat type, during the

Nepalese Journal of Zoology | Online Volume 3 Issue 1 | November 2015 | Page 34 
monsoon season, further significantly contributed to the habitat preference of the rhinos. Some of the preferred food species of the rhinos found in the grassland habitat type of the study area during the monsoon season were, Bhati (Clerodendrum viscosum), Siru Jhar (Imperata cylindrica), Dubo (Cynodon dactylon), Gandhe (Ageratum conyzoides), Neuro (Dryopteris cochleata), Namle Jhar (Coix species), Kuro (Chrysopogon aciculatus), Kans (Saccharum spontaneum), Bansur Jhar; of which, during the study, the rhinos were found frequently feeding on the young leaves and stem of Bhati (Clerodendrum viscosum), Siru Jhar (Imperata cylindrica), Dubo (Cynodon dactylon), Gandhe (Ageratum conyzoides) and Neuro (Dryopteris cochleata).

\section{Conclusion}

The rhinos use four main habitat types, namely, the forest habitat type, the riverbed forest habitat type, the grassland habitat type and the riverside forest habitat type in the study area; where food, water and cover are available. Throughout the year, with the considerable seasonal variations in the availability of food and shelter in the study area, the rhinos move between the different habitats types, thus, resulting in the disproportional use of one resource over the other. In the Baghmara Buffer Zone Community Forest, the rhinos exhibit seasonal differences in the habitat preferences and there is a statistically significant difference in the use of different habitat types by the rhinos between the different seasons of the year as a whole. The rhinos prefer the grassland habitat type the most in the winter season, the forest habitat type in the summer season and the grassland habitat type in the monsoon season. The forest and the short grassland habitat types of the Baghmara Buffer Zone Community Forest, although is still in the succession stage, provide a suitable habitats for the rhinos.

\section{Acknowledgements}

We express our gratitude to the Central Department of Zoology for providing the opportunity to study, the Department of National Parks and Wildlife Conservation, Nepal (DNPWC) for providing the research permission and the Baghmara Buffer Zone Community Forest (BBZCF) for providing the research permit. J.K. Lama, Field Technician, is also highly acknowledged for his kind support.

\section{References}

Baghmara Community Forest (BCF) 1995. Operational Plan of Baghmara Community Forest 1995 to 2000. BCF, Chitwan. 40 pp.

Baghmara Buffer Zone Community Forest (BBZCF) 2003. Operational Plan of Baghmara $\quad$ Buffer Zone Commnity Forest 2003 to 2007. BBZCF, Chitwan. 50 pp.

Chalise, M. K. (2008). Nepalka Samrakshit Banyajantu, (Nepal's Protected Wildlife) in Nepali. Shajha Prakashan, (A Corporate publishing house) Lalitpur Kathmandu Nepal, page 116+12.

Chalise M.K. 2010. Kehi Prakritik Srot ra Vartaman Nepal (Some Natural Resources and Current Nepal). Praagyik Sansar, Central Campus, TU 12 (1): 55-65.

Dinerstein E. 1979. An ecological survey of the Royal Karnali-Bardia Wildlife Reserve, Nepal. Part I: Vegetation modifying factors, and successional relationship. Biol. Conserv. 15:127-150.

IUCN 1990. 1990. IUCN Red List of Threatened Animals. IUCN, Gland Switzerland and Cambridge, UK.

Nepalese Journal of Zoology | Online Volume 3 Issue 1 | November 2015 | Page 35 
Jnawali S.R. 1989. Park People Interaction: Assessment of Crop Damage and Human Harassment by Rhinoceros (Rhinoceros unicornis) in Sauraha Area Adjacent to the Royal Chitwan National Park, Nepal. M.Sc. Thesis. Agriculture University of Norway.

Krebs C.J. 1989. Ecological methodology. Harper Colins College Publishers, New York.

Laurie W.A. 1978. The Ecology and Behavior of the Greater One-horned Rhinoceros. PhD Dissertation, University of Cambridge, Cambridge.

Laurie W.A. 1982. Behavioral Ecology of the Greater One-horned Rhinoceros (Rhinocerosunicornis). Journal of Zoological Society of London. 196:307-341.

Pant P. 2003. Fuel wood Consumption Pattern in low land Nepal: A case study in Baghmara Buffer Zone Community Forest, Chitwan, Nepal. M Sc. Thesis submitted to Pokhara University.

Sharma B.K., Chalise M.K. and Solanki G.S. 2013. Wild ungulates population in Baghamara Buffer zone community forest, Nepal J.Nat. Hist Mus. TU 27: 66-77.

Nepalese Journal of Zoology | Online Volume 3 Issue 1 | November 2015 | Page 36 